DOI https://doi.org/10.30525/978-9934-26-148-0-43

\title{
ПРО ПРИНЦИПИ ПОБУДОВИ ОКРЕМИХ КРИМІНАЛІСТИЧНИХ МЕТОДИК СУДОВОГО ПРОВАДЖЕННЯ
}

\author{
Мирошниченко Ю. М. \\ кандидат юридичних наук, суддя Іллічівського районного суду \\ м. Маріуполя Донеиької області \\ м. Маріуполь, Донещька область, Україна
}

Для ефективного управління процесом, в тому числі судовим, необхідні знання, вміння, досвід. Суб'єкт управління, як мінімум, має розуміти мету своїх дій і володіти знаннями про найбільш ефективні способи іiі досягнення. Якщо обізнаність судді про загальні завдання кримінального судочинства та цілі судового доказування передбачається в силу займаної посади, то знаннями про методи їх реалізації його повинна озброїти криміналістична методика. Криміналістичні алгоритми, що розробляються нею для потреб судочинства, покликані сприяти організації раціональної роботи суддів у кримінальних справах.

Водночас робота зі створення методичних рекомендацій та їх комплексів буде конструктивною за умови їі відповідності низці загальних правил. Практично жодне наукове дослідження монографічного характеру, присвячене проблемам криміналістичної методики, жоден підручник криміналістики або навчальний посібник відповідної тематики не оминає увагою питання принципів побудови окремих криміналістичних методик.

Розглянемо деякі 3 них в аспекті методико-криміналістичного забезпечення судового провадження.

Законність алгоритмів розв'язання криміналістичних ситуацій, які складаються на стадії судового провадження, означає повну й точну відповідність їх змісту чинному законодавству, етичним нормам i моральним принципам. Положення кримінального процесу становлять правову основу побудови методики судового провадження, тоді як остання покликана розкрити особливості застосування інститутів і норм кримінального процесуального права та розробити криміналістичні алгоритми.

Теоретична обгрунтованість і практична застосовність пропонованих рекомендацій вимагає, щоб вони мали вагоме наукове обгрунтування та перевірену на практиці ефективність, враховували як позитивний досвід, так і помилки та недоліки в роботі суддів у кримінальних справах. Базовими для судової методики стануть дані криміналістичної тактики. 
Меншою мірою судова методика використовуватиме досягнення криміналістичної техніки, засоби якої призначені в основному для роботи з речовими доказами, характерної для стадії досудового провадження (виявлення, фіксація, вилучення і т.д.). Разом 3 тим поява нових технічних засобів і технологій, розширення можливостей судової експертизи, поряд з удосконаленням тактичних прийомів і методів впливають на криміналістичну, зокрема й судову, методику, викликаючи необхідність уточнення наявних або створення нових методичних рекомендацій.

Вивчення та теоретичне узагальнення практики судової діяльності в типових ситуаціях судового провадження дозволить визначити ці загальні, найбільш дієві методи, що розробляються не лише криміналістичною наукою, але й виробляються практикою кримінального судочинства. В результаті наукового обгрунтування вони набувають методологічної завершеності. Своєю чергою, судова практика за допомогою зворотного зв'язку інформує розробників про невідповідність методичних рекомендацій завданням, що вирішуються у змінених умовах судочинства, визначає необхідність вдосконалення наявних або розробки нових криміналістичних засобів, прийомів $\mathrm{i}$ рекомендацій, стимулюючи розвиток криміналістичної техніки й тактики.

Принцип конкретності передбачає, реальність тактичних рекомендацій по роботі з доказами, повноту й дієвість розроблюваних алгоритмів, визначеність і точність їх змісту та його відповідність умовам сучасної судової практики, об'єктивності та типовості ситуацій, з якими доводиться стикатися суб'єктам криміналістичної діяльності на стадії судового провадження.

Принцип оперативності судового провадження, продиктований загальною вимогою кримінального процесу про необхідність дотримання розумних строків судового розгляду кримінальних справ (ст. 28 КПК). Оперативність судового розгляду - це оптимальне поєднання процесуальних і криміналістичних засобів 3 метою як найшвидшого досягнення генеральної мети кримінального провадження. Діяти оперативно значить адекватно оцінювати ситуацію, що склалася, швидко приймати необхідні рішення, своєчасно та наполегливо їх реалізовувати. Принцип оперативності судового провадження націлює розробника методико-криміналістичних рекомендацій на забезпечення оптимального темпу ведення судового провадження, коли при найменшій витраті часу досягається найбільший ефект процесуальної діяльності.

Метою криміналістичних методик судового розгляду $є$ організація оптимальної процедури дослідження доказів, наданих сторонами обвинувачення та захисту [1]. Головним методом організації судового 
провадження виступає планування, воно зумовлюється самою суттю методико-криміналістичного забезпечення судового провадження, завданням якого є сприяння суду в тому, щоб, виходячи з ситуації, що склалася у справі, найбільш раціонально організувати судовий розгляд 3 метою його планомірного просування до реалізації стратегічної мети кримінального провадження. Досягнення цієї мети оптимізується застосуванням розроблених на основі теорії планування криміналістичних алгоритмів відповідно послідовним етапам даного процесу.

Кримінально-процесуальній діяльності властива циклічність, що пов'язано з розвитком (зміною) умовно самостійних етапів судового розгляду, в рамках яких, своєю чергою, відбувається трансформація судових ситуацій. У зв'язку з цим актуалізується необхідність створення для суддів альтернативних програм (алгоритмів) у вигляді комплексів тактичних засобів з оптимального розв'язання різних тактичних завдань, що виникають при дослідженні доказів в рамках типових судових ситуацій стосовно етапів судового розгляду окремих категорій кримінальних справ [2].

Виходячи з цього, сутність принципу етапності полягає в тому, що методичні рекомендації найбільш раціонального порядку організації судового дослідження повинні бути диференційовані відповідно до різних етапів судового провадження. При цьому етапи, які визначаються та розробляються в криміналістиці, необхідно відрізняти від стадій кримінального процесу, що вивчаються наукою кримінального процесуального права. Якщо останні відбивають послідовність дій суб'єктів кримінального судочинства в залі судових засідань, то криміналістичні етапи також характеризують особливості організації роботи суду за його межами. Криміналістична програма судового провадження включає періоди до, під час і після проведення підготовчого судового засідання, а також вступну частину судового розгляду, дослідження доказів, судові дебати та останнє слово обвинуваченого, постановлення та проголошення підсумкового рішення у справі.

Однак виділення етапів судового провадження - це тільки узагальнена теоретична модель даного процесу. Для того, щоб наблизити наукові положення до умов судової практики, необхідно розглянути кожен етап з точки зору характерних для нього ситуацій, чого вимагає наступне 3 виділених нами правил побудови криміналістичних алгоритмів судового розгляду - принцип ситуаційності.

Принцип ситуаційності (ситуаційної обумовленості) в нашому розумінні суті методики судового провадження набуває особливого значення. Воно полягає в тому, що на відміну від традиційного для криміналістики конструювання методик розслідування окремих видів злочинів, пріоритет віддається побудові алгоритмів розв'язання типових судових ситуацій, що виникають протягом усього судового прова- 
дження, та характерних для всіх або більшості кримінальних справ безвідносно до кримінально-правової кваліфікації досліджуваної події, що традиційно кладеться в основу створення окремих криміналістичних методик.

Такими в загальних рисах $є$ основні приписи, якими повинен керуватися розробник окремих судових методик. Серед них законність, теоретична обгрунтованість та практична застосовність, конкретність, оперативність, планомірність (етапність), ситуаційна обумовленість. Зрозуміло, що ними не вичерпується вся системи засад створення та функціонування таких побудов. Це швидше той обов'язковий мінімум правил, яким вони мають відповідати. Вочевидь при більш глибокому спеціальному дослідженні можуть бути названі й інші принципи створення окремих методик судового провадження та запропоновані їх класифікаційні системи.

\title{
Література:
}

1. Журавель В. Окрема криміналістична методика: поняття та сфера застосування. Вісник Академї̈ правових наук України. 2011. № 2. С. 202213.

2. Мишин А.В. Особенности криминалистической деятельности в судебном производстве по уголовным делам. Ученые записки Казанского университета. Гуманитарные науки. 2017. Т. 159. Кн. 2. C. 504-511.

DOI https://doi.org/10.30525/978-9934-26-148-0-44

\section{ЗАХИСТ ІНФОРМАЦЇ̈, ОТРИМАНОЇ В РЕЗУЛЬТАТІ ПРОВЕДЕННЯ НЕГЛАСНИХ СЛІДЧИХ (РОЗШУКОВИХ) ДІЙ}

\author{
Цилюрик I. I. \\ кандидат юридичних наук, \\ дочент кафедри кримінального права і прочесу \\ Навчально-наукового Інституту права, психології \\ та інноваційної освіти Національного університету \\ «Львівська політехніка» \\ м. Львів, Украӥна
}

Інформацію, яка отримана в результаті НСРД можна розподілити на дві групи:

- інформація, яка використовується у кримінальному провадженні; 